\title{
Gateway, Instrument, Environment
}

\section{The Aquarium as a Hybrid Space between Animal Fancying and Experimental Zoology}

\author{
Christian Reiß
}

Einfallstor, Instrument, Umwelt. Das Aquarium als hybrider Raum zwischen Haustierhaltung und experimenteller Zoologie

Trotz seiner großen Verbreitung in den Lebenswissenschaften wurde dem Aquarium bisher wenig wissenschaftsund technikhistorische Aufmerksamkeit zuteil. Dies ist nicht zuletzt durch den Umstand begründet, dass das Aquarium und seine Geschichte bisher größtenteils als außerwissenschaftlich aufgefasst wurden. Dabei spielen so unterschiedliche Kontexte wie Akklimatisierung, Amateurnaturkunde und bürgerliche Populärkultur eine wichtige Rolle. Gleichzeitig ist die Entwicklung des Aquariums aber auch eng mit der Geschichte der Lebenswissenschaften verbunden. Mit Blick auf die zweite Hälfte des 19. Jahrhunderts verstehe ich das Aquarium als techno-natural assemblage, in der Technologie, Kultur und Natur zu einem künstlichen Naturraum verbunden sind. Seine Geschichte beginnt in der britischen Amateurnaturkunde und der französischen Akklimatisierungsbewegung. Im Deutschland des späten 19. Jahrhunderts entwickelte sich das Aquarium zu einem Massenphänomen. Gleichzeitig hielt es Einzug in die Lebenswissenschaften, wo es als Einfallstor, Instrument und Umwelt Verwendung fand. Wie sich zeigt, ist das Aquarium eine hochgradig konstruierte Technologie, die sich aus einer Verbindung unterschiedlicher Traditionen herausgebildet und das Leben in die Lebenswissenschaften gebracht hat.

Schlüsse/wörter: Amateurnaturkunde, Liebhaberei, experimentelle Zoologie, Aquarium, Geschichte der Lebenswissenschaften im 19. Jahrhundert

Keywords: Amateur natural history, animal fancying, experimental zoology, aquarium, history of nineteenth century life sciences

When in 1875 August Weismann saw amblystomas for the first time, he was struck. Even though he was familiar with the anatomical description and illustrations Auguste Duméril (Duméril 1866a) had published ten years earlier, it was not until he saw these strange creatures with his own eyes that he realized how much the axolotls had changed in the course of their transformation. They had become "entirely different animals" (Weismann 1875: 240). ${ }^{1}$ This observation confirmed his belief that the transformation could neither be the kind of metamorphosis commonly observed among amphibians nor the progressive evolutionary event that other zoologists had posited. 
While the transformations published by Duméril in 1866 (Fig. 1) had been a surprising and enigmatic event, Weismann's amblystomas were the result of an experiment. Marie von Chauvin, who worked with Weismann in Freiburg, had induced the transformation by carefully altering the living conditions of five axolotls.

Yet in addition to Weismann, Chauvin, Duméril, axolotls and amblystomas, there is another almost invisible, albeit crucial actor in this story - the aquarium. This technological object housed Duméril's first axolotls in Paris, it carried some of their offspring to Weismann in Freiburg and it was used by Chauvin to experimentally alter the axolotls' environment and induce their transformation into amblystomas. And it was a precondition for Weismann's astonishment about the striking difference between the two animal forms. As Weismann emphasized, it was only when he saw the living animals that he realized how deeply the transformation had altered their anatomy and physiology (ibid.). ${ }^{2}$

The Mexican axolotl, which would become a popular experimental animal still in use today (Smith/Smith 1971, Voss/Epperlein/Tanaka 2009), is but one example for the impact of the aquarium on the life sciences in the nineteeth century. In what follows, I first discuss the significance of a history of the aquarium for the history of science and technology. I then compare the British aquarium craze with the situation in France and Germany to illustrate the diverse traditions of European aquarium culture. Focusing on Germany, where aquarium fancying developed into a mass culture, I analyze how aquarium technology developed as a techno-natural assemblage in the context of acclimatization, industrialization and urbanization. I describe how aquaria became a hybrid space in which a particular version of nature was brought into cultural and especially, into domestic spaces. And finally I describe the ways in which

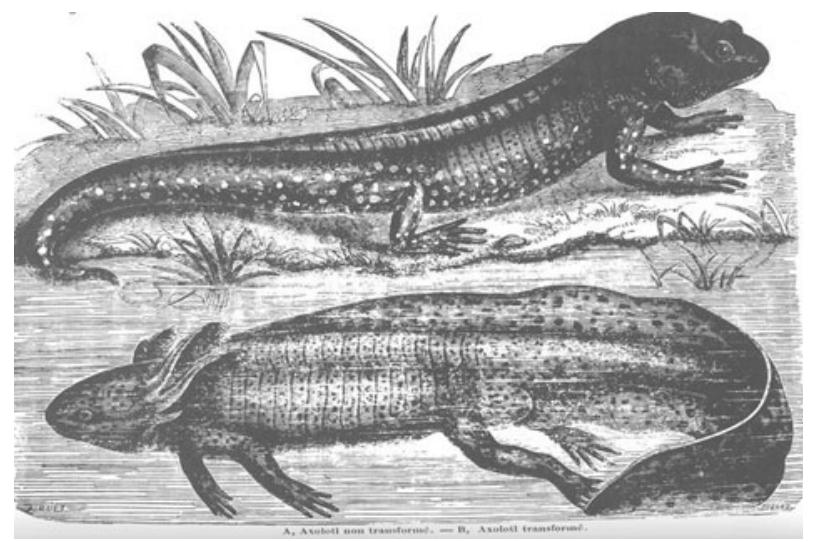

Fig. 1 Axolotl (bottom) and amblystoma (top) as depicted in one of Auguste Duméril's publications (Duméril 1866b: 81). 
aquaria became part of zoological institutes and how they were subsequently used in research.

\section{The Aquarium and the History of Science}

Even though it was and still is an integral part of laboratory research in the biomedical sciences, the aquarium leads a shadowy existence in the history of science and technology. The rare opinions given by historians of science are short and unambiguous. For David Allen, the aquarium was a "plaything of fashion" (Allen 1996: 394) and aquarium fancying an "extra-intellectual interest" (1994: 122) in the context of British amateur natural history. Andreas Daum describes aquarium fancying as yet another variety of popular science in nineteenth century Germany, in which "non-professional nature lovers [aimed] for fulfilment and organization" (Daum 2002: 108). ${ }^{3}$ This article contributes to these and further works that focus on the aquarium's role in nineteenth and twentieth century popular culture (Schlebrügge 2005, Lorenzi 2009, Kranz 2010, Brunner 2011, Hamera 2012). At the same time it challenges the bias towards an extra-scientific history of the aquarium by emphasizing the aquarium's hybrid nature as an object in popular and laboratory culture.

The aquarium shares its fate with a number of elementary/alimentary technologies in the history of science that are so familiar and their use so taken for granted that they "reside in a naturalized background" (Edwards 2003: 185). In recent years, historians of technology like David Edgerton and Paul N. Edwards have argued for a shift in the history of technology from an innovation-centred approach to investigating technologies-in-use or infrastructures, that is, to question especially those technologies and practices that are taken for granted and thus seem unproblematic and almost natural (ibid., Edgerton 2007).

Kijan Espahangizi has raised a similar critique. In his history of laboratory glass, he argues against the epistemological, and thus in a way also innovationcentred approach in the history of science (Espahangizi 2011). Even though there is a general agreement about the importance of technologies and technical artefacts in the history of science and especially in the history of the laboratory, investigations still focus on the epistemological process and the production of knowledge. For Espahangizi this means that technologies are used as an explanans for the explanadum of knowledge production and are only of interest if they are directly related to this context of production. In his concept of historical ecology (historische Ökologie) Espahangizi calls for the inversion of this relation, turning the technological environments of knowledge production into the explanandum. Instead of using the mundane world of technology to explain the production of scientific knowledge, the 
production of scientific knowledge should be used to explain the emergence of a mundane world of technology. As Espahangizi shows, this technological world is the product of a process of functional diversification and compartmentalization of space.

The aquarium is such a functional space and a technology-in-use in twentieth and twenty-first century laboratory culture. Hence there must be a history of its emergence and stabilization and a historical link to its history in the nineteenth century. And this connection must either provide a feedback from Daum's popular science into the professional realm, or the aquarium must have been more than Allen's profane "plaything of fashion".

As I will show in this article, closer inspection reveals that both scenarios apply and that the aquarium indeed has a history of science. It is not just exclusively a history of science, but also a history of fanciers, of animals, of industrial and urban technology and of nature constructed. It is the history of a technology that developed from a broad desire to bring nature into cities, into domestic spaces and - last but not least - into scientific spaces.

These spaces did not emerge as epistemic or experimental spaces in the first place, but as spaces of animal husbandry and fancying. They emerged from a desire to keep animals in domestic, non-agricultural spaces and from the necessities and problems that resulted. At first glance, these necessities and problems seem mundane, but at the same time they were existential as the main concern was the animals' survival and wellbeing. A whole set of practices, technologies and spaces had to be constructed and negotiated between the needs of a diverse set of human and non-human users (Oudshoorn/Pinch 2005).

The result of this constructive process were techno-natural assemblages, in which technology, knowledge, and nature were inextricably intertwined. These assemblages (Latour 2005, Rheinberger 2010 [2006]) functioned as hybrid spaces that made it possible to bring nature into urban and domestic spaces. They became artificial environments (künstliche Naturräume). The emergence of these assemblages had diverse origins and was located in an intermediary realm between science, enthusiasm, and commerce. The life sciences, and zoology in particular, were but one part of this realm, both relying and contributing to it. This both reflected and facilitated the practical changes from collection-based work with preserved specimens in the tradition of natural history to laboratory-based work with living animals. It thereby transformed zoological spaces into spaces of animal husbandry and ultimately animal experimentation. The aquarium can be understood as one such techno-natural assemblage. It was one of the gateways that brought life to the life sciences and thus constituted a different strategy of "naturalizing the lab" (Kohler 2002a). While Kohler describes the ways in which laboratory methods and practices were brought to the field in the context of early ecological research, techno-natural assemblages emerged as a way of shifting the 
lab-field-border in the opposite direction (Kohler 2002b). They brought the field to the lab. Starting from its initial function as a gateway, the aquarium gained additional importance as an instrument and environment in the experimental systems of the life sciences.

\section{The British Aquarium Craze and the Saltwater Aquarium}

In The Naturalist in Britain, David Allen reconstructs the history of the aquarium and the aquarium craze in Britain in the 1840s and 1850s, linking it to a number of other subfields of British amateur natural history (Allen 1994). By way of explaining the spreading of the aquarium and the nature of the aquarium craze, he points to two central factors. First, it was the "removal [...] of the [...] excise duties on glass" (ibid.: 122) that made products of plate glass, including the aquarium, accessible to a broader audience. Second, there was a social change in the "public for natural history" (ibid.). An emerging educated and prosperous middle class turned enthusiasm into a craze.

Aquarium fancying in Britain was materially and practically linked to a set of activities, which all consisted of collecting organisms or parts of them and arranging and displaying them in different kinds of boxes. While in academic natural history, these activities had a long tradition and were based on a taxonomic and classificatory epistemology, amateur crazes followed a different logic.

Driven by the writings of Philip Henry (Gosse 1856) and following on the heels of seaweed and fern fancying, the aquarium offered a new opportunity for members of the emerging middle class to enjoy nature, advance their (scientific) education, and develop and display their aesthetic sensibility. Aquarium fancying originally meant to go to the coast during ebb tide - British aquarium fancying concentrated mainly on saltwater aquaria - to collect plants and animals from the tidal pools and then arrange them in aquaria. With its rising popularity and almost becoming a must-have for the salon, the aquarium became a commodity with a growing industry offering everything from fresh saltwater to fully equipped and even regularly maintained aquaria (Brunner 2011). The most prominent aquarium trader was W. Alford Lloyd, whose Aquarium Warehouse in London had 15,000 animals in stock (Lloyd 1858, Alexander 2005). To secure a steady supply of fresh water, plants, and animals, traders like Lloyd took advantage of the rapidly developing railroad system in Britain, which connected the coast with inland cities like London and allowed a fast and stable transport of the sensitive freight (Schivelbusch 1978). The rising popularity together with the new infrastructural possibilities owing to industrialization meant that soon "[g]reat stretches of the coast were largely stripped of their attractive inhabitants" (Allen 1994: 124). 
Even though enthusiasm evaporated as fast as it had emerged, seeing most aquaria abandoned (Brunner 2011), it left a lasting legacy by laying the foundations of aquarium technology and practices, and thus of techno-natural assemblages. Furthermore, public aquaria made their way to the European continent as a new attraction for the masses. Following the bankruptcy of his aquarium warehouse with the end of the craze, W. Alford Lloyd became the most eminent expert for public aquaria in Europe, constructing aquaria for the Jardin zoologique d'acclimatation in Paris (1860), the Zoologische Garten Hamburg (1864), and the Stazione Zoologica of Naples (1874). In addition, it sparked the proliferation of the aquarium as a research technology in the life sciences. While during the first half of the nineteenth century, scientific research with and on aquaria largely remained an isolated endeavour conducted by people like Robert Warington (Hamlin 1986), Anna Thynne (Stott 2003) or Jeanette Villepreux-Power (Brunner 2011) the use of aquaria became widespread among British anatomists and zoologists (Elwick 2007) from the 1850 s onwards. Thus, not even the British aquarium tradition should be considered a purely amateur movement or as popular science. As I show the amateur-professional dichotomy that already received substantial criticism (Daum 2002, Nyhart 2009, Phillips 2010) does not hold for the situation in France and Germany either.

The history of the British aquarium craze and of the public aquarium reflects a specific tradition in aquarium fancying which is intimately tied to a broad cultural (re-)discovery of the ocean at the beginning of the nineteenth century (Corbin 1994, Rozwadowski 2005, Schwarz 2005). Saltwater aquaria became the focus of this tradition, serving as imaginative spaces of the mysterious and undiscovered wonders of the ocean. In addition, the geographic specificities of Great Britain as an island with a big ratio of coastline to area and the resulting short distances between coast and inland cities simplified their set-up and maintenance.

\section{The Continental Counterpart. Acclimatization, Aquaculture, and the Freshwater Aquarium}

The situation in continental Europe differed from Great Britain in several ways. Due to the geographic differences - less coastline per area and hence long distances between coast and most inland cities - saltwater aquaria never became as popular and common as in Great Britain. Even though adept enthusiasts managed to set up and maintain saltwater aquaria for several years without changing water, the organisms populating the aquarium nevertheless eventually died and had to be replaced by new ones. As breeding turned out to 
be almost impossible for most marine organisms, fresh supply had to come directly from the sea.

This corresponds to the fact that, especially in France and Germany, aquarium fancying was much more rooted in the acclimatization movement with its specific agenda between science, enthusiasm and commerce. The acclimatization movement emerged in France and Great Britain the end of the eighteenth century (Osborne 2000). Due to the rapidly increasing circulation of organisms along colonial networks animals, plants, and humans were frequently exposed to new environments, and the influence of different environments on organisms came into focus. Acclimatization was the attempt to deal with and even to take advantage of this influence. In Great Britain this meant the transfer of organisms between similar environments, while the French approach assumed that organisms could, to a certain degree, be bred to adapt to different environments (ibid.).

The Société imperiale d'acclimatation, the first acclimatization society founded in Paris in 1854, set its agenda accordingly (Osborne 1994). It announced prizes (consisting of medals and considerable sums of money) for the successful introduction and breeding of a wide range of organisms that were considered agriculturally and economically promising in various ways. Its activities were directed both at France as well as at the colonies and included attempts to acclimatize alpacas, zebras, bustards, new silkworm species, new wax-producing insect species and quinine bark in France, edible fish in Algeria, and "an animal to Martinique that could exterminate the fer-de-lance (Bothrops lanceolatus) living there". 4

These examples illustrate the Sociétés policy ranging from projects in France to ones in the colonies, and from agriculture to pharmacy. In parallel to stimulating acclimatization efforts by its members, the Société founded a zoological garden. The Jardin zoologique d'acclimatation was opened in 1860 and designed as a mix between an acclimatization laboratory and public animal display. In the Bois de Boulogne outside Paris, which had been landscaped under the direction of Baron Haussmann into a park in 1852, the Société built what was soon regarded as the ideal of a modern zoological garden. Financed by stock shares and a large network of powerful members, the Jardin was the manifestation of the acclimatization ideology.

The French acclimatization movement must be understood as part of a much broader regenerative movement, which Napoleon III. turned into a state policy during the Second Empire. Projects ranged from Baron Haussmann's urban renewal of Paris to reforestation projects all over France, following the idea of "making facts of nature into instruments of human progress" (Kinsey 2006: 536). Acclimatization was a complex set of practices, which linked "science to animal display, urban renewal, agricultural improvement, and France's colonial mission” (Osborne 1994: 13). 
One of these projects was scientific aquaculture, the attempt to "elevate the last unconquered region of the planet - its aquatic wilderness - to a level of domestication" (Kinsey 2006: 527). The aqua-cultural revolution, like any other regenerative project at this time in France, was carried by heterogeneous interest groups "including scientists, bureaucrats, sportsmen, and entrepreneurs" (ibid.: 552). State and private actors aimed for the rational and scientific reorganization of the use of aquatic species and tried to acclimatize foreign species in French waters, including salt- and freshwater "fish, mollusks, and even leeches for medical purposes" (ibid.: 528). For their Jardin, the Société commissioned W. Alford Lloyd to build an aquarium, which included both salt- and freshwater tanks as well as facilities for fish, oyster, and frog culture. ${ }^{5}$

While committed to the improvement of nature in general, and human food sources in particular, the spectacle of the exotic and ornamental held a prominent place on the acclimatization agenda as well. As a result, aquaria did not only become an integral part of the Jardin but also objects for private homes (Lorenzi 2009). Compared to Great Britain that created a different blend of aquarium culture. The specific mixture of economic and ornamental motives, the inclusion of freshwater aquaria, and especially the close association with imperial networks and acclimatization shifted the attention away from the one-way relation between the ocean and the aquarium toward the breeding and circulation of aquarium organisms within techno-natural assemblages.

\section{The Aquarium in Germany}

The French acclimatization movement and especially its Jardin zoologique d'acclimatation soon acquired European fame, and similar societies and zoological gardens were founded across Europe. Germany was one of the countries where (French) acclimatization found a large following. Zoological gardens were opened or reorganized (Wessely 2008), societies founded, journals published, and a broad affinity to animal keeping and breeding emerged.

While acclimatization and its encompassing improvement agenda turned out to be rather short-lived in Germany, the educational and leisure aspect of animal keeping and breeding acquired increasing prominence. This development was amplified by the particular German tradition of non-academic natural history (Nyhart 2009). In this context, Emil Roßmäßler, the German counterpart to Philip Henry Gosse, promoted the aquarium and set the agenda for German aquarium culture (Roßmäßler 1856, 1857, Daum 2002). As in Great Britain and France, aquarium enthusiasts were members of the middle class with the necessary resources in money, time, and education (Daum 
2002). After the initial boom between the 1870s and 1890s, fancying saw another upswing in the interwar period. During these years, the aquarium found a new audience among members of the working class, and large numbers of proletarian clubs were founded (Hohl 2001b).

The rapid expansion of the field in the late nineteenth century is apparent in the growing number of increasingly specialized journals and the formation of clubs or Vereine. Until the 1870s, Der Zoologische Garten. Zeitschrift für die gesamte Tiergärtnerei (The Zoological Garden. Journal for the Entire Field of Zoo Keeping), founded in 1859, was the most important journal in the field of animal fancying. Originally the journal of the Frankfurt zoological society and its zoo, it soon became the central publication for zoological gardens, acclimatization, and animal breeding in Germany. In 1876, Isis. Zeitschrift für alle naturwissenschaftlichen Liebhabereien. Verkehrsblatt für naturgeschichtlichen Kauf und Tausch (Isis. Journal for all Scientific Hobbies and Natural Historical Trade and Exchange) was launched. It specialized in the needs of the evergrowing private animal fanciers, serving as a platform for the exchange of practical information and to connect animal buyers and sellers (Paepke 2007a). The journal Natur und Haus. Illustrirte Zeitschrift für alle Naturfreunde (Nature and House. Illustrated Journal for all Friends of Nature), founded in 1892, and its follow-up Nerthus: Illustrierte Wochenschrift für Tier- und Pflanzenfreunde.Organ für Sammler und Freunde aller naturwissenschaftlichen Zweige (Nerthus: Illustrated Weekly for Friends of Animals and Plants. Institution for Collectors and Friends of all Scientific Branches), launched in 1899, were directed at similar audiences (Daum 2002).

Isis was only published until 1889, but one year later, in 1890, Blätter für Aquarien- und Terrarien-Freunde. Illustrirte Halbmonatsschrift für die Interessen der Aquarien- und Terrarienliebhabei (Journal for Aquarium and Terrarium Enthusiasts. Illustrated Half-Monthly for the Interests of Aquarium and Terrarium Enthusiasts), was launched as the first journal exclusively for aquarium and terrarium fanciers. This project was initiated by Bruno Dürigen, the co-founder of Isis and one of the most prolific figures in the field of German animal keeping and breeding (Paepke 2007b), and Ernst Bade, former editor of Nerthus and a leading figure in the German aquarium and terrarium scene who ran his own commercial aquarium breeding business in Berlin. The journal's title points to a characteristic of German aquarium culture - the close connection between the aquarium and the terrarium, often subsumed under the umbrella term vivarium. This meant a generally more inclusive approach with a broader array of animals, ranging from fish, amphibians, and reptiles to insects and plants, as well as a more complex set of habitats, which often combined aquatic and terrestrial spaces.

In 1902 the Blätter were renamed Blätter für Aquarien- und Terrarienkunde. Illustrirte Wochenschrift für die Interessen der Aquarien- $u$. Terrarienkunde (Journal for Aquarium and Terrarium Studies. Ilustrated 
Weekly for the Interests of Aquarium and Terrarium Studies) and switched from bimonthly to weekly publication. While the latter indicates the growing author- and readership, the change in the title from Freunde (enthusiasts) to Kunde (studies) points to the effort of enthusiasts to be taken seriously in their activities, which they understood as a form of knowledge production complementary to the sciences (Nyhart 2009). In 1909, Natur und Haus merged with Blätter and in 1939 Blätter merged with its competitor Wochenschrift für Aquarien-und Terrarienkunde (Weekly for Aquarium and Terrarium Studies), founded in 1904.

Aquarium clubs started to appear in the late 1870s. By 1911, 284 clubs existed and could be found in every larger German city (Hohl 2001a). In the same year German aquarium and terrarium fancying saw a further institutionalization with the foundation of the Verband der Aquarien- und Terrarienvereine (Association of Aquarium and Terrarium Clubs) (ibid., 2001b).

This continuing specialization and institutionalization of aquarium and terrarium fancying found no complement in France and Great Britain. Aside from monographs that were regularly published in all three countries, only Germany saw the development of highly specialized, practice-oriented journals and a national network of clubs (Daum 2002). Clubs mostly worked as local communication platforms where a common interest cultivated sociability in the exchange of practices, technologies, knowledge, and organisms. Fancier journals fulfilled the same function at national and sometimes international level, connecting likeminded enthusiasts and the growing number of professional aquarium suppliers and acting as platforms on which knowledge and practices were further negotiated, stabilized, exchanged, and archived. Especially in the second half of the nineteenth century, when the keeping and breeding of organisms in aquaria and terraria was still developing, clubs and journals were crucial in developing, stabilizing, and making accessible the necessary knowledge and technologies. The following examples demonstrate this process of tinkering and stabilising techno-natural assemblages as well as their integration into middle-class life worlds in nineteenth-century Germany.

Water ventilation was the most crucial aspect of running an aquarium. Although hydraulic/pneumatic devices (often in combination with a fountain) (Fig. 2) or spring mechanisms driving a paddle wheel had been available from early on, enthusiasts were constantly experimenting with alternative mechanisms, like small steam engines (Buck 1875) or the growing infrastructures of urban supply. Adolf Sasse, who ran the biggest aquarium shop in Berlin, even made a trip from Berlin to Lübeck to study the apparatus constructed by Heinrich Lenz, director of the local natural history collection, who used the water pressure from the recently installed urban water supply system for ventilation (Sasse 1878).

In Sasse's description of his own efforts to install this apparatus in his apartment, several conflicts of integrating techno-natural assemblages become 


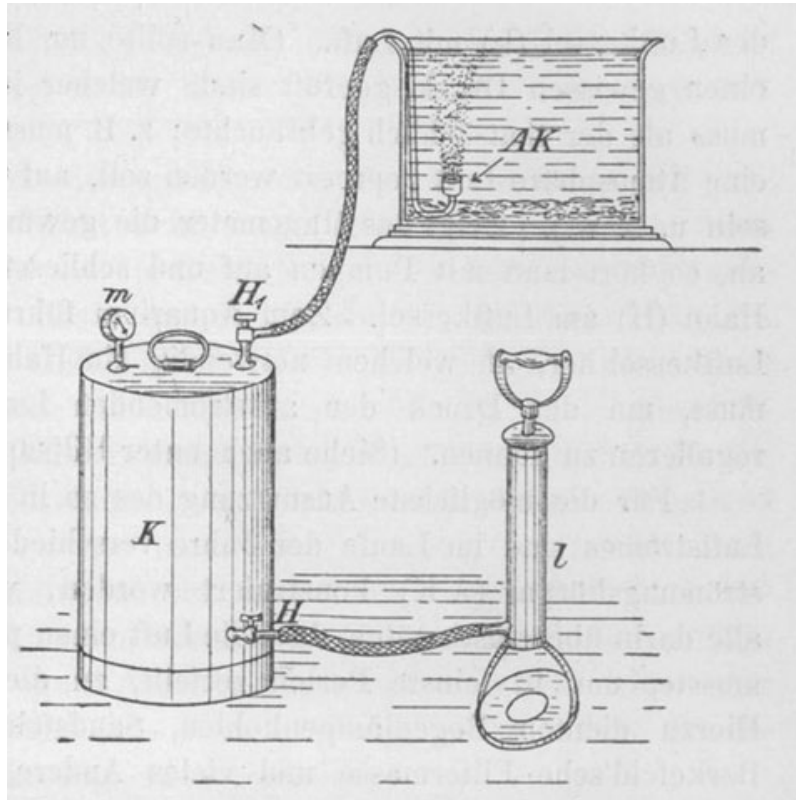

Fig. 2 Construction plan for a ventilation device using an air pump (Zernecke 1897: 41).

visible. The new apparatus had the advantage of replacing the old pump system, which was rather bulky and used to spray water. As Sasse emphasized, "nobody was happier than my wife" (ibid.: 143) ${ }^{6}$ about its disappearance. Still, the new apparatus consisted of a rubber pipe, which ran through three rooms and connected the water tap in the kitchen to the aquaria. In the end it was the landlord who ended "this municipal perpetuum mobile" (ibid.), ${ }^{7}$ complaining about the water running day and night. Sasse had to return to his old pump system. The kind of ventilation device developed by Lenz did not become commercially available until 1908 (Hohl 2001a).

As these examples show, the process of creating a shared space for human and non-human animals went beyond mere technical feasibility and had to meet different interests. The decorative aspects of the aquarium often conflicted with the necessities of maintenance and functionality. The boundary between human and non-human subspaces turned out to be problematic in various ways. Blätter editor Ernst Bade (Bade 1897) brought these boundary issues to the fore when he discussed the following dilemma. If the aquarium is not filled up to the top lip, the water surface leaves a strip of dirt, which over time is more and more difficult to remove and blemishes the aquarium. Yet filling up the aquarium to the seam, one runs the danger that the fish jump out.

Last but not least, aquarium fancying had to be integrated into family life. In a text on aquaria for children from 1899 , the author discussed the question 


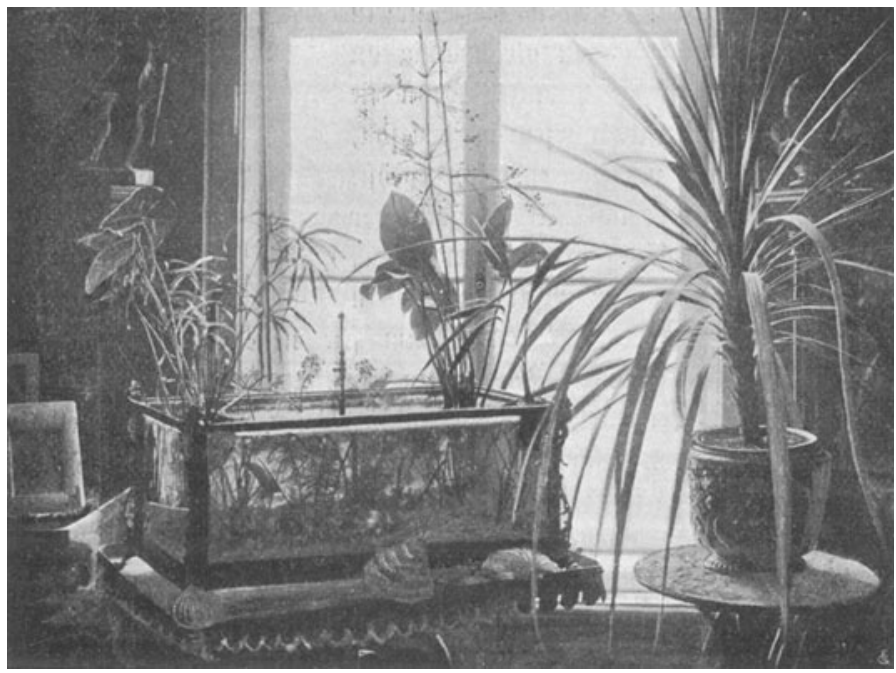

Fig. 3 The aquarium as a techno-natural assemblage, integrated into the urban home (Bade 1899: 72).

why children rarely shared their father's enthusiasm. He identified one reason in the way the aquarium was integrated (or rather, not integrated) into family life. While it often formed the centre of the household, dominating the needs of wives and children, "no wife, no child is allowed in the vicinity of the aquarium, let alone to touch it." (Dankler 1899: 94) ${ }^{8}$

In the course of this mediation between the diverse interests of aquarium animals, family members and landlords, the aquarium became socially and domestically integrated and the techno-natural assemblage developed into a stable and increasingly ready-made infrastructure (Fig. 3). As aquarium fancying found a growing audience, a market developed that was served by a growing number of suppliers. To give just one example of its dimensions: between 1905 and 1912, the company A. Glaschker in Leipzig sold 100,000 aquaria (Hohl 2001b: 117).

\section{The Aquarium in the Sciences}

The process of integrating the aquarium did not only take place in domestic spaces. For a number of partly overlapping reasons, life scientists started to keep animals as well. While many life scientists were fanciers themselves, there were also practical and methodological reasons that created a growing demand for living animals. Even though the aquarium was likewise used in scientific institutions in France (for instance at the Muséum d'Histoire naturelle in Paris) 
and Great Britain (Elwick 2007), the highly diversified German aquarium culture and the development of the life sciences in Germany in the second half of the nineteeth century (Coleman 1971) constituted an especially fertile ground for proliferating the aquarium in the life sciences.

Physiology achieved growing institutional independence and especially experimental physiology developed a research agenda that intensified its consumption of research animals (Nyhart 1995, Dierig 2006). When in 1877 Emil DuBois-Reymond had his new physiological institute built in the centre of Berlin, he included a ranarium, that is, a facility to breed frogs, so as to have a steady supply of frog muscles for his electrophysiological experiments (Dierig 2006). In turn physiologist Elie de Cyon considered the aquarium as the best way to secure this steady supply and he noted that every "experimental scientist should personally make sure that the animals are held under living conditions that fit their nature the most" (de Cyon 1876: 29). ${ }^{9}$ As de Cyon emphasized, the growing urban infrastructures could be easily used for this purpose (Dierig 2006).

In parallel, anatomy and zoology shifted from a systematic to a morphological framework (Nyhart 1996). Instead of studying particular anatomical structures in particular species (often using particular specimens from a collection) to comparatively understand the taxonomic relation of these species, morphology used a number of species from one group as exemplars to understand the history, and thus the development of a structure in the whole group. Gradually, the scope expanded to increasingly fundamental principles and ever-larger taxonomic groups. Since this research was based on the investigation of the successive steps of morphological development, it needed the successive developmental stages of often several animal species. Accordingly, the large collections of dead and preserved specimens gradually lost their significance in this context. Like experimental physiologists, zoologists started to rely on species that were either of great abundance locally or could be kept and bred rather easily (Hopwood 2011). Hence availability slowly outpaced taxonomy.

In this context, experimental embryology emerged as a new field of research. It was a science of, or better, at the sea, with roots in the morphological questions of Entwicklungsgeschichte. After primarily developing at marine stations that were founded on all European coasts in the 1870s and 1880 s, it heavily relied on easy access to eggs and larvae of mostly marine invertebrates (Groeben 2008). As a consequence, decades into the twentieth century, several generations of zoologists and anatomists traveled at least once a year to one of the stations, the most famous being the Stazione Zoologica of Naples (Fantini 2000).

And finally: life history studies, though often less visible, always played an important role in zoology (Nyhart 1996). Following the publication of Darwin's Origin of Species, the interrelations between 
organisms and their environment became an important area of research that was increasingly carried out in the emerging hybrid spaces of techno-natural assemblages.

Especially in the context of experimental embryology and the research style developed at the marine stations, the aquarium gained significance. But this observation should neither suggest that the aquarium was imported into science as readymade technology, nor that there was a clear distinction between amateur and scientific uses of the aquarium. Lynn Nyhart has already brought to attention the importance of "practical naturalists" (Nyhart 2009: 108) for the life sciences and the role played by the "everyday business of keeping the animals alive" (ibid.). Not only people generally considered as amateurs contributed to scientific knowledge; also scientists participated in activities generally considered as amateurish.

Aquarium enthusiast and scientist were often identities of the same person, sometimes being almost unconnected, but sometimes being closely interwoven on the practical level. Probably one of the most (in)famous examples in this context is Paul Kammerer. He started out as an aquarium/ terrarium enthusiast in his youth, became a corresponding member of the Berlin club Triton (Rieck/Mau 2008: 60 f.) and published in the Blätter (Kammerer 1901). In 1902, he started to work at the Biologische Versuchsanstalt in Vienna, also known as the Vivarium. It is no coincidence that Kammerer, known for his special aptness for breeding and keeping amphibians (Rieck/Bischoff 2001, Gliboff 2006, Berz 2009), worked at this institution which was in all aspects designed for keeping, breeding, and experimenting with animals (Reiter 1994, Gliboff 2006, Berz 2009). ${ }^{10}$ But he kept close contact to the aquarium movement, acting as editor for the Blätter from 1908 until 1909.

Other examples include Valentin Haecker, Professor of Zoology at the University of Halle, who had a close relationship to the Vivarium-Halle, one of several local clubs. Some of his doctoral students were members of this club and did their experimental research on aquarium animals (Roßmäßler-Vivarium 2006). Werner Schnakenbeck, for example, published his breeding experiments with the Mexican axolotl in the Blätter (Schnakenbeck 1922a), and his experimental research on the same animal in scientific journals (1922b, 1923). In Jena, Friedrich Maurer, Professor of Anatomy, Ludwig Plate (Levit/Hoßfeld 2006), Ernst Haeckel's successor as Professor of Zoology, Karl Hobstetter, Professor of Veterinary Medicine and Julius Schaxel (Reiß 2007), Associate Professor of Zoology, were all members of the local club Wasserrose e.V. 1913 Jena. The fact that many university libraries in Germany hold a wide variety of fancier journals further demonstrates the close ties between academic life sciences and the intermediary realm of enthusiasm. 


\section{The Hybrid Spaces of Zoology}

The introduction of aquaria into the spaces of zoology was in no way unproblematic. As the following examples will show, integration of the techno-natural assemblages caused the same problems in scientific spaces as it did in domestic ones and ultimately led to the construction of new buildings for the growing discipline of zoology.

When in 1871 Carl Gottfried Semper was appointed Professor of Zoology at the University of Würzburg, the former zoological cabinet was turned into a zoological institute. Despite the thus obtained importance at institutional level (Nyhart 1995), the new zoology institute remained in the rooms of the old cabinet in the university's main building, a former monastery.

In 1873 Semper conducted experimental research on the conditions of growth in the Great Pond Snail (Lymnaeus stagnalis; today Lymnaea stagnalis) (Semper 1873). He kept the snails in small aquaria in his institute and tried to find out the effect of several external conditions on their growth. But the rooms in the old monastery were not suited for this kind of research, though Semper had already rearranged and partly reduced the natural history collection of the zoological cabinet, gaining three small and one big room as well as a hall (Semper 1874a). But still, the water supply was insufficient and the rooms were dark and dusty. Like any other aquarium fancier, Semper and his scientific assistant Johann Wilhelm Spengel had to be resourceful and put a lot of effort into creating suitable conditions. They shared their results with other fanciers in Der Zoologische Garten, publishing on how to run a saltwater aquarium and a new ventilation device (Semper 1874b, Spengel 1875). Other fanciers referenced and described the technological inventions of the Würzburg institute (Buck 1874, Dorner 1874, Noll 1881).

Even though initially Semper had been interested in the influence of natural conditions, his growth experiments turned into experiments on how the institute conditions affected the snails and the aquaria. As it turned out, the effect was an unfavourable one for the snails, eventually killing them. Dust and lack of sunlight negatively affected the growth of the aquarium organisms and thus causing fungi and other kinds of unwanted inhabitants to spread (Semper 1873).

For Semper, aquaria were a crucial part of his research. As early as 1874 he requested a new preparator/taxidermist for his institute, complaining that the technical assistant, who had been responsible for this task before, was now too busy caring for the living animals (Semper 1874a). Some years later, the growing number of aquaria was placed in a specifically refurnished aquarium room in the basement of the old university (Braun 1878). It took another ten years until an entirely new institute was built, which fully met the requirements of Semper's research. In his description of the new institute, Semper's scientific 
assistant August Schuberg emphasized the growing need for adequate buildings in zoology. He argued that while marine zoological stations and even freshwater ones were founded everywhere, university institutes, which still carried out most of the research, often even lacked basic facilities to work with local species, let alone foreign ones (Schuberg 1891).

The new institute was a highly compartmentalized space, designed to integrate a variety of functions and to meet the needs of its human and nonhuman inhabitants (Fig. 4). The main building housed working and teaching facilities, apartments for the technical and scientific staff, a pigeonry, a beehive, aquaria, and a greenhouse with separate heating and concrete basins. But Schuberg pointed out that the large garden was actually the most important part. A fountain and more concrete basins were located in the centre of the estate, between the main building and the pond. The spillover water from the in-house basins formed a small rivulet, which ran through an artificial grotto (at the southern side of the greenhouse) and supplied a large pond together with the spillover from the outdoor basins. The pond covered almost the entire southern part of the estate. An aviary and several stables were projected in the south-western part of the garden. Thus, the new institute offered a wide range of habitats, from aquatic to terrestrial ones; from moderate to tropical climates. The pond, which collected the entire spillover from the basins, was soon populated by a variety of small organisms. These would in turn be used for teaching and research, and, more importantly, to feed other animals.

While the ideas Schuberg saw embodied in the new building were obviously the latest developments in zoological research, they also reflected the contemporary aesthetics of culturalized nature. The greenhouse had "the lovely atmosphere of a small tropical landscape" (ibid.: 8), ${ }^{11}$ the grotto ornament was typical for public aquaria (famously the Berlin aquarium, opened in 1869) and the garden had a fountain, a pond, and a rivulet.

Schuberg's description only hinted at an obvious model for this new type of zoological space. Paul Fraisse, Rudolf Leuckart's scientific assistant at the University of Leipzig, made a more explicit reference in his description of their new zoological institute: "In the same way as the botanical garden belongs to the botanical institute, every zoological institute should have at least a small zoological garden." (Fraisse 1882: 27) ${ }^{12}$ The zoo as a reference again brings to the fore the shift from preserved specimens in collections to living animals. It also showcases the origin of the respective practices in the acclimatization movement with its ornamental notion of nature.

The Leipzig institute had been opened just a few years earlier as the first of its kind (Eggert/Junk/Körner/Schmitt 1905: 428). Like in Würzburg, the garden with "aquaria, terraria, aviaries and a bee house" (Chun 1909: 166) ${ }^{13}$ was regarded as the decisive element of the new institute. Of special importance was the outdoor vivarium divided into partitions "from moist soil to a trout rivulet with all [...] transitions (moor, marsh, stagnant water, flowing 
Situations-Plan.

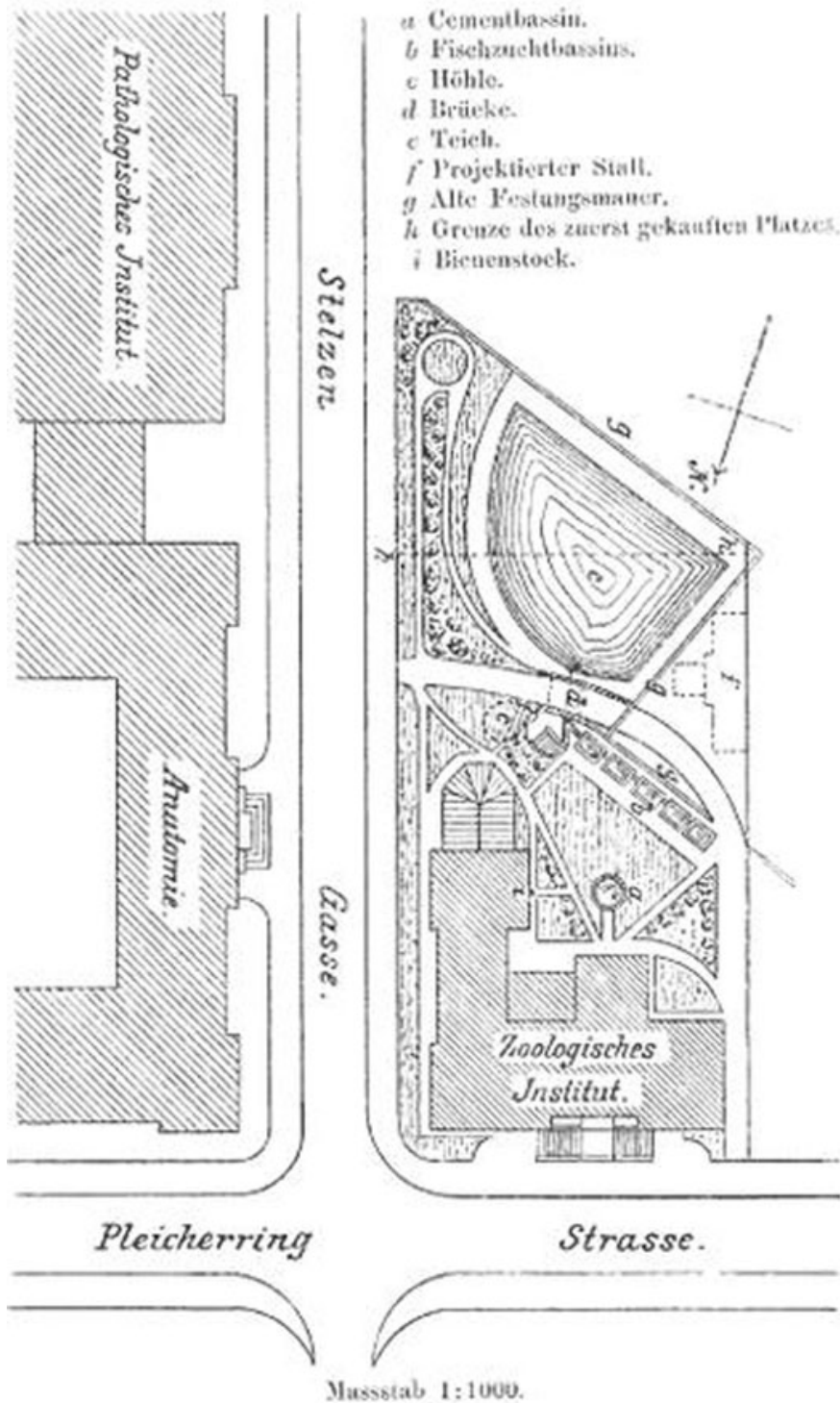

Fig. 4 Site map of Semper's new institute. The greenhouse is attached to the southeastern end of the institute building. The pond covers the southern part of the estate (Schuberg 1891: 11).

water)" (Friedel 1887: 367). ${ }^{14}$ The animals were chosen both as characteristic of the habitats as well as for their suitability for teaching. As the presence of several Mexican axolotls among mostly domestic species shows, the representation of specific local or at least coherent habitats was not the highest priority. When Carl Chun succeeded Leuckart in 1898, aquaria became even 
more central, and a large part of the garden was sacrificed for a new, bigger aquarium, as "modern experimental zoological research makes increasing demands on an aquarium" (Chun 1909: 168). ${ }^{15}$

The last example is August Weismann's institute at the University of Freiburg, taking us back to the axolotls in the introduction. When Weismann came to Freiburg in 1863, zoology did not yet exist as a discipline of its own, but was divided between the physiological and the anatomical institute and the natural history cabinet (Koehler 1957). Only when he became full professor in 1867 did zoology become an independent discipline that was moved from the medical to the philosophical faculty. During that time Weismann's interests shifted from Entwicklungsgeschichte (morphology/embryology) and histology to freshwater organisms and, more famously, to Darwinian evolution and the relation between organism and environment (Churchill 1997, 1999).

Weismann's situation in Freiburg was very similar to Semper's. He had to adapt the existing infrastructure to his research practices. First, he expanded the rooms of his institute that was likewise located in the university's old main building. In 1871, he had a water pipe installed to run aquaria. In 1875 two concrete basins were built in the garden of the main building. Weismann considered these necessary since stagnant waters around Freiburg were vanishing due to land cultivation and urbanization, and aquatic species became less abundant. The installation of the basins required negotiations with the university administration, as they worried that the stagnant water of the basins might dampen the garden's comfortable atmosphere (Koehler 1957: 133).

Weismann's use of aquaria shows the challenges to scientific life and work schedules that this new technology entailed. In 1872 Weismann started the already mentioned research project on the Mexican axolotl. He wanted to find out in the context of his experimental studies on evolution whether the irregular and rare transformation from axolotl to amblystoma August Duméril had observed ten years earlier in Paris (Fig. 1) was caused by environmental influences or the internal phyletic force suggested by other zoologists. What he at first considered to be a straightforward experimentum crucis, which would ultimately show that evolution happened gradually and was driven by natural selection, turned out to be much more complicated. His first experimental attempt failed and all axolotls died. Weismann had left Freiburg for a longer period of time, plus he was also conducting other projects, lacking, as he admitted, "the accuracy and attention in care" (Weismann 1875: 230) ${ }^{16}$ necessary for successful results. Only after he handed the project over to the naturalist Marie von Chauvin did the experiments turn out to be successful (Chauvin 1876). ${ }^{17}$ Her initial interest was in the natural history of insects, but she soon acquired a reputation as a talented and experienced animal breeder (Siebold 1876).

Chauvin used the aquarium as an experimental tool, altering the environmental conditions according to the axolotls' reaction. For her experiments, 
she kept five axolotls in an aquarium that was set up like a lakeshore, that is, only a part was filled with water. To induce the transformation, she slowly lowered the water level so that the animals could only submerge at one spot. During the experiments, Chauvin showed great skill in observing the reaction of the axolotls to the experimental treatment, adjusting the further steps accordingly. The result was the transformation of all five animals. In the course of a subsequent series of experiments she conducted over ten years, she managed to control the axolotls' transformation with the help of the aquarium to the extent that she could start it, stop it, and even reverse it up to a certain point (Chauvin 1883a, 1885). These axolotl experiments were part of a larger experimental system on amphibian metamorphosis, adaptation, and reproduction, on which she also published in the fancier journal Isis. ${ }^{18}$ While the aquarium was often just used as a gateway, which brought new species into research spaces, Chauvin took full advantage of the aquarium as an artificial environment and turned it into an instrument allowing her to manipulate ontogenetic processes in several amphibian species.

Though Weismann soon lost interest in the axolotls, his affinity to research with aquaria remained (Koehler 1957). But he tended to be rather unreliable concerning the handling of the techno-natural assemblage. This inattentiveness caused considerable damage in the university building, as the aquaria regularly overflowed. The university administration tried to hold Weismann's technical assistant responsible for the damage. Besides Weismann's odd work schedule and his unreliability, the assistant brought forward in his defence that he had not been sufficiently instructed and thus was in no way capable of handling the water pipe system or the aquaria (ibid.). Finally, a new zoology building was opened in Freiburg in 1886. Similar to Würzburg and Leipzig, the new facilities included an aquarium room in the basement, an animal house, as well as four outdoor basins in the institute's garden (Stengel 1898).

The three cases are just examples for a broader development. Technonatural assemblages with their artificial environments began to play an important role in zoological research in the late nineteenth century (Eggert/ Junk/Körner/Schmitt 1905: 428-444). And aquaria were the most important ones (ibid.: 432). They provided scientists with material for research and teaching and became research technologies themselves. In many ways, the new zoological institutes became small zoological worlds, in which research was then carried out. In contrast to Robert Kohler's labscapes, this process was not about bringing the lab to the field but the other way round (Kohler 2002b). The field was brought to the lab, or better, the field was reconstructed in the lab. This happened on a large scale and was not restricted to the still exceptional marine and field stations but affected regular university institutes. Furthermore, these new zoological practices did not only facilitate spatial 
reconfigurations but also required modifications in the division of labour and the adaptation of scientific work schedules.

\section{The Aquarium as Gateway, Instrument, and Environment}

In several ways, the hybrid spaces of the aquarium turned out to be indispensable for the life sciences. They became part of the almost industrial laboratory animal production and use in experimental physiology, genetics, and later molecular biology with its notorious model organisms (Dierig 2006, Kirk 2008, Ankeny/Leonelli 2011). It was in part owing to acclimatization and amateur enthusiasm that aquaria and terraria became gateways for foreign animals. Species like the Mexican axolotl (Ambystoma mexiancum), the African clawed frog (Xenopus laevis), and the zebrafish (Danio rerio) started out as aquarium animals and became widely used experimental animals and even model systems (Gurdon/Hopwood 2002, Endersby 2007). ${ }^{19}$

In the context of emerging experimentalism in zoology, a crucial issue was how to obtain suitable and easily available material for research and teaching. The experimental turn in morphological research happened, as mentioned above, at marine stations where scientists conducted empirical studies and collected material. But this research style gradually became problematic with the discipline precipitously starting to grow at the end of the nineteenth century. The first problem was that not everyone could afford the trip to the sea. Also, a growing number of students had to be introduced to the specific research methods. Hence, alternative means to allow experimental research at home had to be found. The amphibian egg and amphibians in general turned out to be such alternatives. In an 1893 paper on the experimental regeneration of germ layers in amphibians, the German embryologist Dietrich Barfurth, working in Dorpat (today Tartu, Estonia), described the amphibian egg as the "pièce de résistance for the poor people who are prevented from a longer stay at the sea due to work and other obstacles" (Barfurth 1893: 313). ${ }^{20}$

The second problem applies to both marine and domestic organisms like amphibians. Their reproductive cycle made research material accessible only in certain intervals - in most cases only once a year. This set a very slow pace for experimental research, forcing it into an archaic annual, almost agricultural cycle. Artificial environments like Semper's institute in Würzburg, with their different habitats and the possibility to alter them, offered the opportunity to manipulate these cycles. Accordingly Semper did not only study the relation between organisms and environment but also used his aquaria to develop methods to regularly procure eggs of animals like the Mexican axolotl for embryological studies (Semper 1878). 
Apart from supplying experimental research, aquaria were also crucial for the emergence of a particular form of proto-ecological research and its conceptualization. Scientist like Semper, who published his book Animal Life as Affected by the Natural Conditions of Existence in 1880, but also Karl Möbius (Nyhart 2009), Otto Zacharias (Nöthlich/Wetzel/Hoßfeld/Olsson 2006), and Jakob von Uexküll (Espahangizi 2011) were aquarium users who drew on their experiences with aquarium keeping in their versions of interrelations and dependencies in nature. ${ }^{21}$ While the history of ecology mainly focuses on field sciences and disciplines explicitly oriented towards "ecological" questions (Kohler 2002b), the lessons learned by the very need to keep especially aquatic animals alive are still neglected. Setting up and running the often fragile techno-natural assemblage of an aquarium required substantial knowledge about the interrelations of its different components and brought them to their users' attentions.

\section{The Aquarium as a Bridge between Animal Fancying and Experimental Zoology}

The aquarium literally brought life to the life sciences. But the transition from specimen collections to vivaria was not unproblematic. It had far-reaching consequences, since the keeping and breeding of animals was by no means a straightforward activity and had to become part of scientific life. Everything from spatial arrangements to work schedules had to be reorganized to fit the needs of both animals and scientists. Crucial in this process was an intermediary realm in which both academic and non-academic enthusiasts worked on the creation of a techno-natural assemblage to establish and sustain artificial environments. Aquarium fancying constituted such an intermediary realm where knowledge, practices, technologies, and organisms were developed and circulated. The outcome was a dynamic process in which the needs of humans and animals were as crucial as aspects of urban middle-class aesthetics and conceptions of nature. The laboratory with its diversification into functional spaces must be considered in some respects as a result of this process and the aquarium as an integral part of it. The history of the aquarium shows that not only did more applied disciplines in the life sciences heavily rely on animal fancying and colonialism, but so did fields like experimental zoology. The focus on practices and technologies like the aquarium offers an entrance to this history that in large parts still remains to be written.

The very practice of keeping and breeding animals made a difference in the scientific practices of the respective fields. As gateway, instrument, and environment, the aquarium did so in various ways. It brought a plethora of new species into zoological spaces. While these living animals as such already made 
an obvious difference to zoologists like Weismann, the aquarium also affected the available range of research organisms. Furthermore, it was applied to adapt the supply of experimental animals to the requirements of research methods and served as an instrument. But it also drew attention to the environment itself and its complex interrelations. All of these contexts have to be considered if we want to analyze the aquarium as a techno-natural assemblage. As middleclass aesthetic conceptions of nature and mundane constraints during its integration into domestic and scientific spaces were crucial in its development, they also influenced the nature contained in it. Naturalness was only one of a range of desirable and achievable conditions.

It was only at the beginning of the twentieth century that the aquarium infrastructure reached a stable state and the intermediary space lost importance. The aquarium became ready-made and elaborate systems could be bought off the shelf. Only then, after the most existential problems had been solved and a hybrid space for human and non-human animals had been established, did the aquarium become important for those scientists who were not enthusiasts, too. As it became unproblematic and subsequently taken for granted, the aquarium infrastructure went the way which Paul N. Edwards has shown to be characteristic for all infrastructures: It "reside[d] in a naturalized background" (Edwards 2003: 185).

\section{Acknowledgments}

I would like to thank my supervisor Uwe Hoßfeld for his support and helpful comments on this paper; Joanna Radin for her insightful comments, which triggered the transformation of an older version into the present text; Sophia Roosth for comments and her help with the English phrasing; Mareike Vennen for being the other aquarium nerd and for fruitful discussions; Nils Güttler, Michael Markert, Rob Kirk, Hans-Jörg Rheinberger, Henning Schmidgen, Skúli Sigurdsson for detailed comments; three anonymous referees for their helpful criticism; the editors of NTM for comments and additional copy-editing. Last but not least, I would like to thank Dr. Dieter Hohl for kindly providing information on the history of the club Rossmäßler-Vivarium in Halle and Wolfram Buhler for generously granting me access to the archives of Wasserrose e.V. 1913 Jena.

\section{End notes}

1 In the original: "ganz andre Thiere".

2 This paper is part of my $\mathrm{PhD}$ project (Friedrich-Schiller-Universität Jena) on the history of the Mexican axolotl (Ambystoma mexicanum) as an experimental animal in the life sciences.

3 In the original: "nichtprofessionellen Naturfreunde nach Entfaltung und Organisation [suchten]".

4 Preise für Acclimatisation. Der Zoologische Garten, 1 (1859), 12-14, hier 13-14. In the original: "eines Thieres auf Martinique, das die dortige Lanzenotter (Bothrops lanceolatus) vertilgen könnte."

5 cf. Correspondenzen und Nachrichten aus anderen Zoologischen Gärten. Der Zoologische Garten, 1 (1860), 180-182. 
6 In the original: "niemand war froher als meine Frau".

7 In the original: "diesem städtischen Perpetuum mobile".

8 In the original: "durfte keine Frau, kein Kind auch nur in die Nähe des Heiligtums kommen, noch weniger mit einem Finger daran rühren".

9 In the original: "Kein Experimentator sollte es verschmähen, durch persönliche Ueberwachung dafür Sorge zu tragen, dass die Thiere immer unter Lebensbedingungen gestellt werden, die ihrem Wesen am meisten entsprechen".

10 It is rather telling that Kammerer is remembered very differently by scientists and aquarium/terrarium enthusiasts. While in science and in the history of science, his alleged fraud is the central issue (Gliboff 2006), this episode is only of minor interest for the enthusiasts and even interpreted in his favor (Rieck/Bischoff 2001).

11 In the original: "den hübschen Charakter einer kleinen Tropenlandschaft".

12 In the original: "Wie der Botanische Garten zum Botanischen Institut, so gehört eigentlich zu jedem zoologischen Institut ein, wenn auch nur kleiner, Zoologischer Garten."

13 In the original: "Aquarien, Terrarien, Volieren und ein Bienenhaus".

14 In the original: "feuchten Erdboden bis zum strömenden Forellenbächlein, in allen Übergangen (Moor, Sumpf, stehendes Wasser, fließendes Wasser)”.

15 In the original: "moderne experimentelle zoologische Forschung an ein Aquarium erhöhte Anforderungen stellte".

16 In the original: "wenig Pflege und Aufmerksamkeit".

17 Marie von Chauvin was born in Berlin on 21 December 1848 as the daughter of Franz von Chauvin, a colonel general in the Prussian army, who had introduced telegraphy to the military. Her mentor was Carl Theodor von Siebold, professor of zoology at the University of Munich. In the early 1870s, she moved with her family from Berlin to Freiburg. After a series of publications between 1876 and 1885, she disappears from the record. In the late 1910s, she still lived in Freiburg under her maiden name and was involved in the fancying of mesembs (Schwantes 1920). Her date of death is unknown.

18 Cf. Chauvin 1876, 1877, 1882, 1883a, 1883b, 1883c, 1885.

19 The zebra fish was first imported to Germany in 1905 by Paul Matte, the most important ornamental fish breeder in Germany around 1900 (Vereinigte Zierfisch-Züchtereien in Rahnsdorfer Mühle 1914, Endersby 2007).

20 In the original: "pièce de résistance für die armen Leute, denen ein längerer Aufenthalt an der See durch Beruf und andere Fesseln unmöglich gemacht wird".

21 Zacharias was member of the Berlin club Triton and Möbius had at least a close relationship (Rieck/Mau 2008: 60 f.).

\section{References}

Alexander, Bob, 2005. William Alford Lloyd.[http://www.parlouraquariums.org.uk/Pioneers/ lloyd1.html; http://www.parlouraquariums.org.uk/Pioneers/lloyd2.html; http://www. parlouraquariums.org.uk/Pioneers/lloyd3.html (last accessed: 13 August 2012)].

Allen, David E., 1994. The Naturalist in Britain: A Social History. Princeton: Princeton University Press.

Allen, David E., 1996. Tastes and Crazes. In: Nicholas Jardine, James A. Secord and Emma C. Spary, eds., Cultures of Natural History. Cambridge: Cambridge University Press, 394-407.

Ankeny, Rachel A./Leonelli, Sabina, 2011. What's so Special about Model Organisms? Studies in History and Philosophy of Science Part A, 42, 313-323.

Bade, Ernst, 1897. Wie verhindert man das Herausschnellen der Fische aus ganz gefüllten Behältern. Blätter für Aquarien- und Terrarien-Freunde, 8, 6-7.

Bade, Ernst, 1899. Praxis der Aquarienkunde (Süßwasser-Aquarium, Seewasser-Aquarium, AquaTerrarium). Magdeburg: Creutz'sche Verlagsbuchhandlung. 
Barfurth, Dietrich, 1893. Experimentelle Untersuchung über die Regeneration der Keimblätter bei den Amphibien. Anatomische Hefte, 3, 309-354.

Berz, Peter, 2009. The Eyes of the Olms. History and Philosophy of the Life Sciences, 31, 215-240.

Braun, Max, 1878. Die Einrichtung des zoologischen Instituts Würzburg zur Zucht der Thiere. 1. Aquarien. Zoologischer Anzeiger, 1, 34-36.

Brunner, Bernd, 2011. Wie das Meer nach Hause kam. Die Erfindung des Aquariums. Berlin: Wagenbach.

Buck, Emil, 1874. Die Stromerzeugungsmaschine für das Süsswasser-Aquarium. Der Zoologische Garten, 15, 148-150.

Buck, Emil, 1875. Die Stromerzeugungsmaschine für das Aquarium. Der Zoologische Garten, 16, 17-20.

Chauvin, Marie von, 1876. Ueber die Verwandlung der mexicanischen Axolotl in Amblystoma. Zeitschrift für wissenschaftliche Zoologie, 27, 522-535.

Chauvin, Marie von, 1877. Ueber das Anpassungsvermögen der Larven von Salamandra atra. Zeitschrift für wissenschaftliche Zoologie, 29, 324-350.

Chauvin, Marie von, 1882. Vorläufige Mittheilung über die Fortpflanzung des Proteus anguineus. Zoologischer Anzeiger, 5, 330-332.

Chauvin, Marie von, 1883a. Über die Fortpflanzung des Amblystoma. Zoologischer Anzeiger, 6, 513-515.

Chauvin, Marie von, 1883b. Ueber die Fortpflanzung des Amblystoma. Isis. Zeitschrift für alle naturwissenschaftlichen Liebhabereien, 8, 321-322.

Chauvin, Marie von, 1883c. Die Art der Fortpflanzung des Proteus anguineus. Zeitschrift für wissenschaftliche Zoologie, 38, 671-685.

Chauvin, Marie von, 1885. Ueber die Verwandlungsfähigkeit des mexikanischen Axolotl. Zeitschrift für wissenschaftliche Zoologie, 41, 365-389.

Chun, Carl, 1909, Das Zoologische Institut. In: Rektor und Senat, eds., Festschrift zur Feier des 500jährigen Bestehens der Universität Leipzig. Band 4: Die Institute und Seminare der philosophischen Fakultät an der Universität Leipzig: 1409-1909. Teil 2: Die mathematischnaturwissenschaftliche Sektion. Leipzig: Hirzel, 157-168.

Churchill, Frederick B., 1997. Life Before Model Systems: General Zoology at August Weismann's Institute. American Zoologist, 37, 260-268.

Churchill, Frederick B., 1999. August Weismann: A Developmental Evolutionist. In: Frederick B. Churchill und Helmut Risler, eds., August Weismann. Ausgewählte Briefe und Dokumente. Freiburg: Universitätsbibliothek Freiburg i. Br., 749-798.

Coleman, William, 1971. Biology in the Nineteenth Century. Problems of Form, Function, and Transformation. New York: Wiley.

Corbin, Alain, 1994. The Lure of the Sea. The Discovery of the Seaside in the Western World 17501840. Berkeley: University of California Press.

Cyon, Elie de, 1876. Methodik der Physiologischen Experimente und Vivisectionen. Gießen: Ricker.

Dankler, M., 1899. Jugendaquarien. Blätter für Aquarien- und Terrarien-Freunde, 10, 94-96.

Daum, Andreas W., 2002. Wissenschaftspopularisierung im 19. Jahrhundert. Bürgerliche Kultur, naturwissenschaftliche Bildung und die deutsche Öffentlichkeit, 1848-1914. München: Oldenbourg.

Dierig, Sven, 2006. Wissenschaft in der Maschinenstadt. Emil Du Bois-Reymond und seine Laboratorien in Berlin. Göttingen: Wallstein.

Dorner, H[...], 1874. Eine neue Verbesserung der Zimmeraquarien. Der Zoologische Garten, 15, $41-45$.

Duméril, Auguste, 1866a. Observations sur la reproductions dans la ménagerie des reptiles du Muséum d'Histoire Naturelle, des axolotls, batraciens urodèles à branchies extérieures du Mexique, sur leur développment et sur leur metamorphoses. Nouvelles Archives du Muséum d'Histoire Naturelle, 2, 265-292.

Duméril, Auguste, 1866b. Observations faites a la ménagerie du muséum d'histoire naturelle sur la reprodution des Axolotls batraciens urodéles a branchies extérieures et sur les métamorphoses qu'ils y ont subies. Bulletin de la société imperiale zoologique d'acclimatation, 3, 79-89.

Edgerton, David, 2007. The Shock of the Old. Technology and Global History since 1900. Oxford: Oxford University Press. 
Edwards, Paul N., 2003. Infrastructure and Modernity. Force, Time, and Social Organization in the History of Sociotechnical Systems. In: Thomas J. Misa, Philip Brey and Andrew Feenberg, eds., Modernity and Technology. Cambridge: MIT Press, 185-225.

Eggert, Hermann/Junk, Carl/Körner, Carl/Schmitt Eduard, 1905. Hochschulen im allgemeinen. Universitäten und Technische Hochschulen. Naturwissenschaftliche Institute. In: Eduard Schmitt, ed., Handbuch der Architektur. 4. Teil: Entwerfen, Anlage und Einrichtung der Gebäude. 6. Halbband: Gebäude für Erziehung, Wissenschaft und Kunst. Heft 2: Hochschulen, zugehörige und verwandte wissenschaftliche Institute. Stuttgart: Alfred Kröner Verlag, 1-454.

Elwick, James, 2007. Styles of Reasoning in the British Life Sciences. Shared Assumptions, 1820 1858. London: Pickering \& Chatto.

Endersby, Jim, 2007. A Guinea Pig's History of Biology. London: William Heinemann.

Espahangizi, Kijan, 2011. The Twofold History of Laboratory Glassware. In: Mathias Grote, Max Stadler and Laura Otis, eds., Membranes, Surfaces and Boundaries. Interstices in the History of Science, Technology and Culture. Berlin: Preprints of Max Planck Institute for the History of Science, 17-33.

Fantini, Bernardino, 2000. The ,Stazione Zoologica Anton Dohrn' and the History of Embryology. International Journal of Developmental Biology, 44, 523-535.

Fraisse, Paul H., 1882. Die Zuchträume des zoologischen Instituts der Universität Leipzig. Der Zoologische Garten, 23, 17-28.

Friedel, Ernst, 1887. Tierleben und Tierpflege in Leipzig und Umgegend. Der Zoologische Garten, 28, 361-367.

Gliboff, Sander, 2006. The Case of Paul Kammerer: Evolution and Experimentation in the Early Twentieth Century. Journal of the History of Biology, 39, 525-563.

Gosse, Philip Henry, 1856. The Aquarium. An Unveiling of the Wonders of the Deep Sea. London: John Van Voorst.

Groeben, Christiane, 2008. Tourists in Science. Ninetheenth Century Research Trips to the Mediterranean. Proceedings of the California Academy of Sciences, 59, 139-154.

Gurdon, John B./Hopwood, Nick, 2002. The Introduction of Xenopus laevis into Developmental Biology. Of Empire, Pregnancy Testing and Ribosomal Genes. International Journal for Developmental Biology, 46, 49-63.

Hamera, Judith, 2012. Parlor Ponds. The Cultural Work of the American Home Aquarium, 18501970. Ann Arbor: University of Michigan Press.

Hamlin, Christopher, 1986. Robert Warington and the Moral Economy of the Aquarium. Journal of the History of Biology, 19,131-153.

Hohl, Dieter, 2001a. Von den vivaristischen Anfängen bis zur VDA-Gründung. In: Verband Deutscher Vereine für Aquarien- und Terrarienkunde e.V., ed., Festschrift zum 90jährigen Jubiläum. Beiträge zur Geschichte der Aquaristik und Terraristik in Deutschland. Bochum: Verband Deutscher Vereine für Aquarien- und Terrarienkunde e.V, 13-72.

Hohl, Dieter, 2001b. Ein Verband bestimmt die Entwicklung. Die Zeit von 1911 bis 1933. In: Verband Deutscher Vereine für Aquarien- und Terrarienkunde e.V., ed., Festschrift zum 90jährigen Jubiläum. Beiträge zur Geschichte der Aquaristik und Terraristik in Deutschland. Bochum: Verband Deutscher Vereine für Aquarien- und Terrarienkunde e.V, 73-121.

Hopwood, Nick, 2011. Approaches and Species in the History of Vertebrate Embryology. In: Francisco J. Pelegrini, ed., Vertebrate Embryogenesis: Embryological, Cellular and Genetic Methods. New York: Humana Press, 1-20.

Kammerer, Paul, 1901. Die Querzahnmolche (Amblystoma). Blätter für Aquarien- und TerrarienFreunde, 12, 166-169, 177-180.

Kinsey, Darin, 2006. ,Seeding the Water as the Earth': The Epicenter and Peripheries of a Western Aquacultural Revolution. Environmental History, 11, 527-566.

Kirk, Robert G. W., 2008. ,Wanted-Standard Guinea Pigs'. Standardisation and the Experimental Animal Market in Britain ca. 1919-1947. Studies in History and Philosophy of Science Part C, 39, 280-291.

Koehler, Otto, 1957. Die Zoologie der Universität Freiburg i. Br. In: Eduard Zentgraf, ed., Aus der Geschichte der Naturwissenschaften an der Universität Freiburg. Freiburg: Albert, 129-144.

Kohler, Robert E., 2002a. Labscapes: Naturalizing the Lab. History of Science, 40, 473-500.

Kohler, Robert E., 2002b. Landscapes E Labscapes: Exploring the Lab-Field Border in Biology. Chicago/London: University of Chicago Press. 
Kranz, Isabel, 2010. 'Parlor oceans', ,crystal prisons'. Das Aquarium als bürgerlicher Innenraum. In: Thomas Brandstetter, Karin Harasser and Günther Freisinger, eds., Ambiente. Das Leben und seine Räume. Wien: Turia + Kant, 155-176.

Latour, Bruno, 2005. Reassembling the Social. An Introduction to Actor-Network-Theory. Oxford: Oxford University Press.

Levit, Georgy S./Hoßfeld, U., 2006. The Forgotten ,Old Darwinian' Synthesis. The Evolutionary Theory of Ludwig H. Plate (1862-1937). NTM. Internationale Zeitschrift für Geschichte und Ethik der Naturwissenschaft, Technik und Medizin,14, 9-25.

Lloyd, W. Alford, 1858. A List, with Descriptions, Illustrations, and Prices of Whatever Relates to Aquaria. London: Hayman Brothers.

Lorenzi, Camille, 2009. L'engouement pour l'aquarium en France (1855-1870). Sociétés E Représentations, 2, 253-271.

Nöthlich, Rosemarie/Wetzel, Nadine/Hoßfeld, Uwe/Olsson, Lennart, 2006. „Ich acquirirte das Schwein sofort, ließ nach dem Niederstechen die Pfoten abhacken u. schickte dieselben an Darwin“ - Der Briefwechsel von Otto Zacharias mit Ernst Haeckel (1874-1898). Annals of the History and Philosophy of Biology, 11,177-248.

Noll, Friedrich Carl, 1881. Mein Seewasser-Zimmeraquarium. Der Zoologische Garten, 22, 8-19, 33-42, 71-79, 137-147, 168-177, 194-206.

Nyhart, Lynn K., 1995. Biology Takes Form. Animal Morphology and the German Universities, 1800-1900. Chicago: University of Chicago Press.

Nyhart, Lynn K., 1996. Natural History and the ,New' Biology. In: Nicholas Jardine, James A. Secord and Emma C. Spary, eds.,Cultures of Natural History. Cambridge: Cambridge University Press, 426-446.

Nyhart, Lynn K., 2009. Modern Nature. The Rise of the Biological Perspective in Germany. Chicago: University Of Chicago Press.

Osborne, Michael A., 1994. Nature, the Exotic, and the Science of French Colonialism. Bloomington: Indiana University Press.

Osborne, Michael A., 2000. Acclimatizing the World. A History of the Paradigmatic Colonial Science. In: Roy McLeod, ed., Nature and Empire: Science and the Colonial Entreprise, [= Osiris, 15]. Chicago/London: University of Chicago Press, 135-151.

Oudshoorn, Nelly/Pinch, Trevor J., 2005. How Users Matter. The Co-Construction of Users and Technology. Cambridge, Mass.: MIT Press.

Paepke, Hans-Joachim, 2007a. Die ,Isis'. Eine Vorläuferin vivaristischer und anderer naturkundlicher Zeitschriften. Aquaristik-Fachmagazin, 39, 72-79.

Paepke, Hans-Joachim, 2007b. Prof. Dr. hc. Bruno Dürigen, his Life and his Achievements in the Fields of Herpetology, Vivarium- and Poultry Science. Mitteilungen des Museums für Naturkunde zu Berlin. Zoologische Reihe, 83, 74-82.

Phillips, Denise, 2010. Reconsidering the Sonderweg of German Science. Biology and Culture in the Nineteenth Century. Historical Studies in the Natural Sciences, 40, 136-147.

Reiß, Christian, 2007. No Evolution, no Heredity, just Development-Julius Schaxel and the End of the Evo-Devo Agenda in Jena, 1906-1933. A Case Study. Theory in Biosciences, 12, 155-164.

Reiter, Wolfgang L., 1994. Zerstört und Vergessen. Die Biologische Versuchsanstalt und ihre Wissenschaftler/innen. Österreichische Zeitschrift für Geschichte, 10, 585-614.

Rheinberger, Hans-Jörg, 2010 [2006]. An Epistemology of the Concrete: Twentieth-Century Histories of Life. Durham: Duke University Press [German original: Epistemologie des Konkreten. Studien zur Geschichte der modernen Biologie. Frankfurt a. M.: Suhrkamp].

Rieck, Werner/Bischoff, W., 2001. Paul Kammerer (1880-1926). In: Werner Rieck, Gerhard Hallmann and Wolfgang Bischoff, eds., Die Geschichte der Herpetologie und Terrarienkunde im deutschsprachigen Raum. Rheinbach: Deutscher Gesellschaft für Herpetologie und Terrarienkunde, 483-488.

Rieck, Werner/Mau, K.-G., 2008. Eine Vereinschronik 1888-2008. 120 Jahre „Triton“ Gesellschaft für Vivarienkunde 1888 e.V. - zu Berlin - Verein für allgemeine Naturkunde, Aquarien-, Terrarien-, Insektarienkunde und Naturschutz. Berlin: Eigenverlag.

Roßmäßler, Emil Adolf, 1856. Der See im Glase. Die Gartenlaube, 19, 252-256.

Roßmäßler, Emil Adolf, 1857. Das Süßwasseraquarium. Eine Anleitung zur Herstellung und Pflege desselben. Leipzig: Hermann Mendelssohn. 
Roßmäßler-Vivarium [1906] 2006. Verein für Aquarien- und Terrarienfreunde Halle (Saale). 1906-2006 - Festschrift zum 100-jährigen Jubiläum. Halle: Roßmäßler-Vivarium.

Rozwadowski, Helen M., 2005. Fathoming the Ocean. The Discovery and Exploration of the Deep Sea. Cambridge, MA.: Belknap Press of Harvard University Press.

Sasse, Adolf, 1878. Mein Seewasser-Zimmeraquarium. Der Zoologische Garten, 19, 141-148.

Schivelbusch, Wolfgang, 1978. Railroad Space and Railroad Time. New German Critique, 14, 3140.

Schlebrügge, Elisabeth, 2005. Das Meer im Zimmer. Von Tintenschnecken und Muscheltieren. Graz: Landesmuseum Joanneum.

Schnakenbeck, Werner, 1922a. Die selbstgezüchtete Landform des Axolotls. Blätter für Aquarienund Terrarienkunde, 33, 28-29.

Schnakenbeck, Werner, 1922b. Zur Analyse der Rassenmerkmale der Axolotl. II. Die Entstehung und das Schicksal der epidermalen Pigmentträger. Zeitschrift für induktive Abstammungsund Vererbungslehre, 27, 178-226.

Schnakenbeck, Werner, 1923. Über Alterssakromelanismus der Axolotl. Berichte über die gesamte Physiologie und experimentelle Pharmakologie, 20, 19.

Schuberg, August, 1891. Das neue zoologisch-zootomische Institut der Königl. Julius-Maximilians-Universität zu Würzburg. Arbeiten aus dem Zoologisch-Zootomischen Institut in Würzburg, 10, 1-12.

Schwantes, Gustav, 1920. Mesembryanthemum chauviniae. Monatsschrift für Kakteenkunde, 30, $77-78$

Schwarz, Angela, 2005. „Seaside Studies“. Eine populäre Freizeitbeschäftigung von Reisenden ans Meer im England des 19. Jahrhunderts. In: Karlheinz Wöhler, ed., Erlebniswelten. Herstellung und Nutzung touristischer Welten. Münster: Lit-Verlag, 71-85.

Semper, Carl G., 1873. Ueber die Wachsthums-Bedingungen des Lymnaeus stagnalis. Sitzungsberichte der physikalisch-medizinischen Gesellschaft zu Würzburg, 4, 50-79.

Semper, Carl G., 1874a. Das zoologisch-zootomische Institut der Universität Würzburg. Arbeiten aus dem zoologisch-zootomischen Instituts in Würzburg, 1, 1-8.

Semper, Carl G., 1874b. Bemerkungen über den Apparat zum Halten von niederen Seethieren. Der Zoologische Garten, 15, 46-48.

Semper, Carl G., 1878. Über eine Methode, Axolotleier derzeit zu erzeugen. Zoologischer Anzeiger, $1,176-179$.

Semper, Carl G., 1880. Die natürlichen Existenzbedingungen der Thiere. Leipzig: Brockhaus.

Siebold, Carl Theodor von, 1876. Zusatz zu den Mittheilungen über die Verwandlung des Axolotl in Amblystoma. Zeitschrift für wissenschaftliche Zoologie, 27, 536-540.

Smith, Hobart M./Smith, Rozella B., 1971. Synopsis of the Herpetofauna of Mexico. Vol. 1: Analysis of Literature on the Mexican Axolotl. Augusta: Lundberg.

Spengel, Johann Wilhelm, 1875. Der Durchlüftungsapparat für Zimmeraquarien. Der Zoologische Garten, 16, 451-453.

Stengel, Leopold Freiherr von, 1898. Gebäude der Universität. In: Badischer Architecten- und Ingenieur-Verein. Oberrheinischer Bezirk Freiburg im Breisgau, ed., Freiburg im Breisgau Die Stadt und ihre Bauten. Freiburg: Universitätsdruckerei und Verlagsanstalt H. M. Poppen und Sohn, 498-528.

Stott, Rebecca, 2003. Theatres of Glass: the Woman who Brought the Sea to the City. London: Short Books.

Vereinigte Zierfisch-Züchtereien in Rahnsdorfer Mühle, ed., 1914. Die exotischen Zierfische in Wort und Bild. Braunschweig: Kommissionsverlag Gustav Wenzel \& Sohn.

Voss, Randal S./Epperlein H.H./Tanaka E.M., 2009. Ambystoma mexicanum, the Axolotl. A Versatile Amphibian Model for Regeneration, Development, and Evolution Studies. Cold Spring Harbor Protocols 2009, doi:10.1101/pdb.emo128 [last accessed: 22 September 2012].

Weismann, August, 1875. Studien zur Descendenz-Theorie. Band II: Über die letzten Ursachen der Transmutationen. Leipzig: Wilhelm Engelmann.

Wessely, Christina, 2008. Künstliche Tiere. Zoologische Gärten und urbane Moderne. Berlin: Kadmos.

Zernecke, Ernst, 1897. Leitfaden für Aquarien- und Terrarienfreunde. Berlin: G. Schmidt. 
Christian Reiß

Max-Planck-Institut für Wissenschaftsgeschichte

Boltzmannstraße 22

14195 Berlin

Germany

E-Mail: christianreiss@web.de 